\title{
PEMBELAJARAN BIOLOGI DI-SMP KABUPATEN SORONG; KAJIAN RESPON SISWA TERHADAP EFEK PEMBENTUKAN KOMUNITAS BELAJAR MANDIRI
}

\author{
SUTARJO
}

MAN Model Kota Sorong

\begin{abstract}
ABSTRAK
Penelitian ini bertujuan untuk mengetahui efek pembentukan komunitas belajar mandiri untuk olimpiade sains biologi terhadap respon siswa yang mengikuti komunitas belajar mandiri dan mengetahui perbandingan antar sampel. Penelitian dilaksanakan di SMP Negeri 4 Sorong dan SMP IT Nurul Yaqin Sorong pada tanggal 24 April sampai 30 Mei tahun 2014, dengan mengunakan populasi siswa masing-masing sebanyak 257 siswa dan sebanyak 167 siswa. Sampel yang digunakan adalah siswa kelas VII-VIII pada kedua sekolah tersebut dengan jumlah 45 siswa. Penelitian yang digunakan adalah penelitian deskriptif kuantitatif dengan analisis komperatif. Instrumen yang digunakan adalah angket, yang diuji validitas dan uji reabilitas. Hasil uji validitas berdasarkan hasil uji para pakar, instrument yang digunakan valid. Data angket berdistribusi homogen dan tidak semua normal. Hasil uji Mann-Whitney SMP Negeri 4 Sorong yakni probabilitas $=0.869>\alpha=0.05$, hasil uji t two sampel independen SMP IT Nurul Yaqin Sorong yakni thitung $=0.761<$ ttabel $=2.06$, dan hasil uji t two sampel independen antara SMP Negeri 4 Sorong terhadap SMP IT Nurul Yaqin Sorong yakni thitung $=1.263<$ ttabel $=2.09$, sehingga tidak ada perbedaan respon siswa sebelum dan sesudah pembentukan komunitas belajar mandiri dan tidak ada perbedaan respon siswa antar sekolah. Namun, berdasarkan fakta grafik manual, hasil wawancara dan angket guru menunjukkan bahwa, pembentukan komunitas belajar mandiri dapat memotivasi belajar siswa khususnya dalam pembelajaran biologi.
\end{abstract}

Kata kunci: Komunitas, Nurul Yaqin, Belajar, Mandiri, Sorong.

\section{ABSTRACT}

This study is carried out with the purpose to know the effect of the autonomous learning community forming for biology sains olimpiad to the studen's respon who follow that learning community. This study also had purpose to know a comparing between those sample in this study. This research had done in SMP Negeri 4 Sorong and SMP IT Nurul Yaqin Sorong, on April 24 th until may 30 th, on 2014. The populations in this study were students of class VII until VIII from both of scholl the number of sample was 45 students. This study used descriptive quantitative by using comperative analysis. The instrumen was used in this study was questionnaire, and had been test its validity and reability, the test result of validity based on the test of experts that the instrumen used is valid. The data of questionnaire had homogen distribution and those items were not all had normality. The test result or Mann -Whitney SMP Negeri 4 Sorong was probability $=0.869>\alpha=0.05$, the test result of $t$ two sample independent SMP IT Nurul Yaqin Sorong was thitung $=0.761<$ ttabel $=2.06$, and the test result of t two sample independent between SMP Negeri 4 Sorong and SMP IT Nurul Yaqin Sorong was thitung $=1.263<$ ttabel $=2.09$. But, based on the fact of manual graphic, the result of interview and tteacher's questionnaire showed that forming of autonomous learning community can motivate the students to learn, especially in learning biology.

Keywords : Community, Nurul Yaqin, study, self, Sorong.

\section{PENDAHULUAN}

Pendidikan Nasional telah diatur dalam undang.-undang. Undang- undang SISDIKNAS No. 20 tahun 2003 menyatakan bahwa "tujuan pendidikan nasional adalah mencerdaskan kehidupan bangsa dan mengembangkan manusia Indonesia seutuhnya yaitu manusia yang bertaqwa terhadap Tuhan Yang Maha Esa dan berbudi pekerti yang luhur, memiliki pengetahuan dan keterampilan, kesehatan jasmani dan rohani, kepribadian yang mantap dan mandiri serta tanggung jawab kemasyarakatan dan kebangsaan[i]. Kemajuan siswa dalam pendidikan adalah harus belajar melalui demokrasi yang terlibat dalam pembelajaran yang mendorong perkembangan siswa yang demokratis. Demokratis adalah salah satu di mana perpecahan antara kelompok-kelompok[ii]. Progresif seseorang yang demokratis adalah konsepsi sosial dimana pendidikan demokratis memberikan kesempatan untuk berpartisipasi dalam belajar aktif[iii]. Berpartisipasi dalam belajar aktif adalah aktivitas siswa dalam keterlibatan proses pembelajaran[iv]. Pembelajaran pada dasarnya adalah sebagai alat untuk meningkatkan nilai prestasi siswa dalam belajar melalui proses menulis dan berpikir[v]. Pembelajaran juga dapat membantu siswa memahami materi serta bertanggung jawab[vi].

Pedoman pembelajaran dalam pendidikan yakni kurikulum, namun Brand[vii], menunjukkan bahwa kurikulum pendidikan saat ini belum memenuhi kebutuhan sebagian besar siswa. Salah satu kekurangan kebutuhan siswa terletak pada kesenjangan yang signifikan dalam keterampilan pemecahan masalah antara siswa SMP yang kesenjangannya hadir diantara para siswa bagaimana memahami materi pelajaran 
terkhususnya dalam bidang ilmu sains khusus biologi.

Kurikulum pendidikan dalam pembelajaran siswa harus menjadi lebih pragmatis, akal, kreatif, dan fleksibel kurikulum agar siswa mampu berpikir kritis dan mampu memecahkan masalah dalam bersaing[viii]. Dimana kurikulum pendidikan non formal dalam pembelajaran dilengkapi dengan kegiatan ekstrakulikuler[ix]. Salah satunya untuk memecahkan masalah dalam bersaing yakni Olimpiade Sains, maka diadakan komunitas belajar mandiri untuk olimpiade sains. Komunitas belajar mandiri untuk olimpiade sains merupakan pendidikan di luar jam pelajaran yang ditujukan untuk membantu perkembangan peserta didik, sesuai dengan kebutuhan, potensi, bakat, dan minat mereka melalui kegiatan yang secara khusus diselenggarakan oleh pendidik dan atau tenaga kependidikan yang berkemampuan dan berkewenangan di sekolah[x]. Pendidikan non formal dilingkungan akademik dapat dilakukan dengan cara pembentukan les privat[xi], tambahan jam belajar[xii], kursus[xiii], ekstrakulikuler belajar mandiri siswa[xiv] dan komunitas belajar. Komunitas belajar mandiri siswa dibentuk untuk menciptakan ketertarikan siswa dalam proses belajar guna olimpiade sains. Namun, pembentukan komunitas belajar mandiri siswa guna olimpiade sains di SMP Kabupaten Sorong belum pernah dilakukan. Maka perlu dilakukan pembentukan komunitas belajar mandiri guna olimpiade sains biologi di SMP Kabupaten Sorong. Namun, Pembentukan komunitas belajar mandiri olimpiade sains biologi, siswa juga perlu dilakukan penelitian agar diketahui respon siswa terhadap dampak pembentukan komunitas belajar mandiri. Tujuan penelitian ini adalah untuk mengetahui respon siswa tentang efek pembentukan komunitas belajar mandiri guna olimpiade sains biologi dan untuk mengetahui perbandingan sampel eksperimen antar SMP Negeri 4 Sorong (P.4) dan SMP IT Nurul Yaqin Sorong (P.IT).

\section{METODE PENELITIAN}

Metode penelitian yang digunakan dalam penelitian ini adalah penelitian eksperimen (eksperiment riseach). Penelitian eksperimen ini dikaji secara kuantitatif dan kualitatif. Kajian kuantitatif yaitu kajian tentang data yang dikumpulkan dan dinyatakan dalam bentuk angka-angka[xv], seperti nilai/skor prestasi siswa, sedangkan kajian kualitatif adalah kajian tentang data sebagai pendukung penelitian, seperti kata-kata atau kalimat yang tersusun dalam angket.

Pada penelitian ini instrumen sebelum diberlakukan komunitas belajar mandiri dan instrumen sesudah diberlakukan komunitas belajar mandiri. Kelompok tidak dilakukan pengacakan, melainkan menggunakan kelompok atau kelas yang telah ada. Populasi dalam pelaksanaan penelitian ini adalah seluruh siswa di P.4 sebanyak 257 siswa dan P.IT sebanyak 167 siswa tahun pelajaran 2013/2014. Sampel dalam penelitian di P.4 yang meliputi siswa kelas VII-VIII yang terdiri dari kelompok kontrol sebanyak 10 siswa serta kelompok eksperimen sebanyak 9 siswa dan sampel dalam penelitian di P.IT yang meliputi siswa kelas VII-VIII yang terdiri dari kelompok kontrol sebanyak 13 siswa serta kelompok eksperimen sebanyak 13 siswa.

Bahan atau materi penelitian ini adalah soal-soal olimpiade sains nasional biologi dan materi-materi pendukung yang relevan. Instrument yang digunakan adalah Angket atau kuesioner, Wawancara, dan Dokumentasi. Uji Instrumen dalam penelitian adalah Uji Reliabilitas dan Uji Validitas. Penelitian ini dilakukan di P.4 dan P.IT. Data yang telah terkumpul dalam penelitian ini dianalisis dengan mengunakan teknik statistic. Setiap data di hitung menggunakan aplikasi SPSS 18 untuk mempermudah penelitian dalam perhitungan. Teknis analisis data pada penelitian ini dapat dibagi menjadi: Uji Prasyarat penelitian ini yaitu Uji Homogenitas Sampel dan Uji Normalitas Data. Uji Hipotesis yang digunakan adalah Uji Parametrik (Uji t two dependen dan Uji t - 2 Sampel Bebas) dan Uji Nonparametrik (Uji Wilcoxon Sign Rank dan Uji Mann Whitney).

\section{PEMBAHASAN}

Data Hasil Penelitian diperoleh dan disajikan dalam bentuk tabel dan grafik. Selanjutnya dianalisis untuk menjawab permasahan penelitian. Instrumen angket sebelum diberlakukan kepada sampel penelitian maka dilakukan uji prasyarat yang dilaksanakan pada peserta didik diluar sampel yang digunakan sebagai uji prasyarat instrumen awal sebanyak 15 siswa uji prasyarat instrumen untuk mengetahui validitas dan relibilitas guna mengetahui apakah instrumen tersebut layak atau tidak digunakan dalam penelitian. Hasil uji prasyarat angket awal diperoleh data seperti ditunjukkan pada Gambar. 3.1. Hasil angket awal diperoleh skor rata-rata item penyataan yakni antara 3,8 sampai 4,7 . Item pernyataan yang memperoleh skor tertinggi yakni pada item nomor 11 dan item pernyataan yang memperoleh skor terendah yakni item nomor 7 dan 8. Instrumen angket sebelum diberlakukan kepada sampel penelitian maka dilakukan uji prasyarat yang dilaksanakan pada hari Kamis tanggal 29 April Tahun 2014 di P.4. Jumlah peserta didik diluar sampel yang digunakan peneliti sebagai uji prasyarat instrumen akhir sebanyak 15 siswa untuk mengetahui validitas pernyataan dan relibilitas pernyataan untuk mengetahui apakah instrumen tersebut layak atau tidak sebagai suatu instrumen dalam penelitian. Hasil uji prasyarat angket akhir diperoleh data seperti ditunjukkan pada Gambar. 3.1. Hasil angket akhir diperoleh skor rata-rata item penyataan yakni antara 3, 8 sampai 4,5 . Item pernyataan yang memperoleh skor tertinggi yakni item pernyataan nomor 1, 3, 9 dan 10, serta item pernyataan yang memperoleh skor terendah yakni item pernyataan nomor 6 dan 7 .

Data pada penelitian ini berupa data hasil angket awal dan angket akhir. Sehingga diperoleh hasil data sebagai berikut adalah Angket awal diberlakukan kepada 10 siswa dari kelompok kontrol sebelum 
pembentuka komunitas belajar mandiri diperoleh data seperti ditampilkan pada Gambar 3.1. Gambar 3.1 menunjukkan bahwa item pernyataan memperoleh skor rata-rata antara 2,9 hingga 4,8. Skor rata-rata tertinggi yang diperoleh yakni item nomor 10 dan 15, sedangkan item pernyataan yang memperoleh skor rata-rata terendah yakni pada item nomor 7 . Selain itu, angket awal disebarkan kepada 9 siswa dari kelompok eksperimen sebelum pembentukan komunitas belajar mandiri diperoleh data seperti ditampilkan pada Gambar 3.1. Gambar 3.1 menunjukkan bahwa item pernyataan memperoleh skor rata-rata antara 3 hingga 5. Skor rata-rata tertinggi yang diperoleh yakni item nomor 4 dan 12, sedangkan item pernyataan yang memperoleh skor rata-rata terendah yakni pada item nomor 7.

Angket akhir diberlakukan kepada 10 siswa dari kelompok kontrol di P.4 sesudah diberlakukan pembentukan komunitas belajar mandiri diperoleh data

Tabel 3.1 Hasil Angket Respon Guru

\begin{tabular}{|c|c|c|c|c|c|c|c|c|c|c|}
\hline \multirow{2}{*}{ Nama } & \multicolumn{10}{|c|}{ PERNYATAAN } \\
\hline & 1 & 2 & 3 & 4 & 5 & 6 & 7 & 8 & 9 & 10 \\
\hline \multicolumn{11}{|c|}{$\begin{array}{ll}\text { SMP } & \text { Negeri } 4 \text { Sororng }\end{array}$} \\
\hline Jumlah & 12 & 11 & 11 & 9 & 9 & 11 & 11 & 13 & 12 & 13 \\
\hline Rata-rata & 4 & 3.7 & 3.7 & 3 & 3 & 3.7 & 3.7 & 4.3 & 4 & 4.3 \\
\hline Min & 3 & 3 & 3 & 3 & 3 & 3 & 3 & 4 & 4 & 4 \\
\hline $\operatorname{Max}$ & 5 & 4 & 4 & 3 & 3 & 4 & 4 & 5 & 4 & 5 \\
\hline \multicolumn{11}{|l|}{ SMP IT NY Sorong } \\
\hline Jumlah & 13 & 12 & 12 & 12 & 12 & 12 & 13 & 12 & 13 & 13 \\
\hline Rata-rata & 4.3 & 4 & 4 & 4 & 4 & 4 & 4.3 & 4 & 4.3 & 4.3 \\
\hline Min & 4 & 4 & 4 & 4 & 4 & 4 & 4 & 4 & 4 & 4 \\
\hline Max & 5 & 4 & 4 & 4 & 4 & 4 & 5 & 4 & 5 & 5 \\
\hline
\end{tabular}

Tabel 3.1 menunjukkan bahwa dari 10 item pernyataan memperoleh skor rata-rata antara 3 hingga 4.3. Skor rata-rata tertinggi yakni pada item nomor dan 10, sedangkan item pernyataan yang memperoleh skor rata-rata terendah yakni pada nomor item 4 dan 5 .

Angket awal disebarkan kepada 13 siswa dari kelompok kontrol yang diberlakukan di P.IT. Hasil angket awal kelompok kontrol sebelum pembentukan komunitas belajar mandiri diperoleh data seperti ditampilkan pada Gambar 3.1. Gambar 3.1 menunjukkan bahwa item pernyataan memperoleh skor rata-rata antara 3 hingga 4,9. Skor rata-rata tertinggi yang diperoleh yakni pada item nomor 14 , sedangkan item pernyataan yang memperoleh skor rata-rata terendah yakni pada item nomor 7 .

Angket akhir disebarkan kepada 13 siswa dari kelompok kontrol yang diberlakukan di P.IT. Hasil angket akhir kelompok kontrol sesudah pembentukan komunitas belajar mandiri diperoleh data seperti ditampilkan pada Gambar 3.1. Gambar 3.1 menunjukkan bahwa item pernyataan memperoleh skor rata-rata antara 3,7 hingga 4,5. Skor rata-rata tertinggi yang diperoleh yakni pada item nomor 9, sedangkan item pernyataan yang memperoleh skor rata-rata terendah yakni pada item nomor 8 .

Hasil angket guru disebarkan kepada tiga guru perwakilan dari respon guru di P.IT dengan hasil perhitungan angket guru seperti ditampilkan pada seperti ditampilkan pada Gambar 3.1. Gambar 3.1 menunjukkan bahwa item pernyataan memperoleh skor rata-rata antara 3.7 hingga 4,7 . Skor rata-rata tertinggi yang diperoleh yakni item nomor 3,9 dan 10, sedangkan item pernyataan yang memperoleh skor rata-rata terendah yakni pada item nomor 6 dan 7 . Selain itu, angket akhir disebarkan kepada 9 siswa dari kelompok eksperimen di berlakukan di P.4 sesudah diberlakukan pembentukan komunitas belajar mandiri diperoleh data seperti ditampilkan pada Gambar 3.1. Gambar 3.1 menunjukkan bahwa item pernyataan memperoleh skor rata-rata antara 4. 1 hingga 5. Skor rata-rata tertinggi yang diperoleh yakni pada item nomor 12, sedangkan item pernyataan yang memperoleh skor rata-rata terendah yakni pada item nomor 4. Hasil angket guru sesudah pembentukan komunitas belajar mandiri diperoleh data seperti ditampilkan pada Tabel 3.1.
Tabel.3.1. Tabel 3.1. menunjukkan bahwa dari 10 item pernyataan diperoleh rata-rata 4 hingga 4.3 . skor rata-rata tertinggi yakni pada item pernyataan nomor 2 , $3,4,5,6$ dan 8. Sedangkan skor rata-rata terendah yakni pada item pernyataan nomor $1,7,9$, dan 10 .

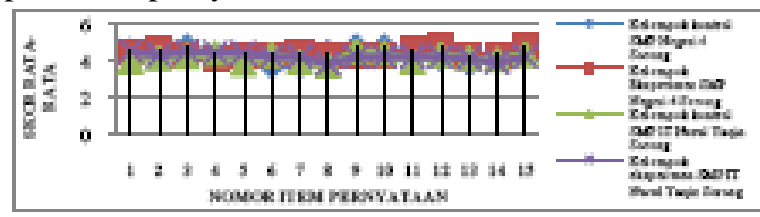

Gambar 3.1. Grafik Perbandingan Antar Kelompok

Hasil perhitungan uji prasyarat ditampilkan pada Tabel 3.1. Hasil uji reabilitas yang menyatakan bahwa angket awal dan instrument akhir dianggap reliabel dan dapat digunakan sebagai instrumen. Hasil uji validitas menyatakan bahwa angket awal dan angket akhir tidak semua berkolerasi signifikan valid dan perlu diperbaiki. Dalam perbaikan angket tidak dihitung secara statistic melainkan mengunakan uji pakar. Hasil uji homogenitas yang diperoleh dari P.4 dan P.IT hasil yang diperoleh adalah homogen. Uji normalitas dari 8 komponen hanya satu komponen pada kelompok kontrol P.4 yang tidak berdistribusi normal.

Hasil perhitungan uji parametric dan uji nonparametrik dari P.4 dan P.IT ditampilkan pada Tabel 3.2. pada semua komponen dinyatakan bahwa H0 diterima. 
Tabel 3.2. Hasil Uji Penelitian.

\begin{tabular}{|c|c|c|c|c|}
\hline komponen & uji & Nilai Uji & Nilai banding & Keputusan \\
\hline Reabilitas Angket Awal & Reabilitas & $\begin{array}{l}\mathrm{r} \text { hitung }= \\
0,708\end{array}$ & $\begin{array}{l}>\mathrm{r} \text { tabel }= \\
0.5140\end{array}$ & reliabel \\
\hline Reliabilitas Angket Akhir & Reabilitas & $\begin{array}{l}\mathrm{r} \text { hitung }= \\
0,828\end{array}$ & $\begin{array}{l}>\mathrm{r} \text { tabel }= \\
0.5140\end{array}$ & reliabel \\
\hline Homogenitas SMP Negeri 4 Sorong & Homogenitas & 0,541 & $>0,05$ & Homogen \\
\hline Homogenitas SMP IT Nurul Yaqin Sorong & Homogenitas & 0.765 & $>0.05$ & Homogen \\
\hline Homogenitas Antar sekolah & Homogenitas & 0.210 & $>0.05$ & Homogen \\
\hline Normalitas Kelompok Kontrol Awal SMP Negeri 4 Sorong & Shapiro-Wilk & 0.205 & $>0.05$ & Normal \\
\hline Normalitas Kelompok Kontrol Akhir SMP Negeri 4 Sorong & Shapiro-Wilk & 0.001 & $<0.05$ & $\begin{array}{l}\text { Tidak } \\
\text { Normal }\end{array}$ \\
\hline Normalitas Kelompok Eksperimen Awal SMP Negeri 4 Sorong & Shapiro-Wilk & 0.211 & $>0.05$ & Normal \\
\hline Normalitas Kelompok Eksperimen Akhir SMP Negeri 4 Sorong & Shapiro-Wilk & 0.568 & $>0.05$ & Normal \\
\hline Normalitas Kelompok Kontrol Awal SMP IT Nurul Yaqin Sorong & Shapiro-Wilk & 0.349 & $>0.05$ & Normal \\
\hline Normalitas Kelompok Kontrol Akhir SMP IT Nurul Yaqin Sorong & Shapiro-Wilk & 0.294 & $>0.05$ & Normal \\
\hline $\begin{array}{l}\text { Normalitas Kelompok Eksperimen Awal SMP IT Nurul Yaqin } \\
\text { Sorong }\end{array}$ & Shapiro-Wilk & 0.395 & $>0.05$ & Normal \\
\hline $\begin{array}{l}\text { Normalitas Kelompok Eksperimen Akhir SMP IT Nurul Yaqin } \\
\text { Sorong }\end{array}$ & Shapiro-Wilk & 0.519 & $>0.05$ & Normal \\
\hline Hipotesis Kelompok Kontrol SMP Negeri 4 Sorong & wilcoxon Sign Rank & 0.624 & $>0.05$ & H0 diterima \\
\hline Hipotesis Kelompok Eksperimen SMP Negeri 4 Sorong & $\begin{array}{l}\mathrm{t} \quad \text { two } \\
\text { dependent }\end{array}$ & $\begin{array}{l}\text { thitung } \\
0.048\end{array}$ & $<$ ttabel $=2.31$ & H0 diterima \\
\hline $\begin{array}{l}\text { Hipotesis Kelompok Kontrol terhadap Kelompok Eksperimen } \\
\text { SMP Negeri } 4 \text { Sorong }\end{array}$ & Mann-Whitney & 0.869 & $>0.05$ & H0 diterima \\
\hline Hipotesis Kelompok Kontrol SMP IT Nurul Yaqin Sorong & $\begin{array}{l}\mathrm{t} \quad \text { two } \\
\text { dependent }\end{array}$ & $\begin{array}{l}\text { thitung } \\
0.000\end{array}$ & $<$ ttabel $=2.18$ & H0 diterima \\
\hline Hipotesis Kelompok Eksperimen SMP IT Nurul Yaqin Sorong & $\begin{array}{l}\mathrm{t} \quad \text { two } \\
\text { dependent }\end{array}$ & $\begin{array}{l}\text { thitung } \\
1.167\end{array}$ & $<$ ttabel $=2.18$ & H0 diterima \\
\hline $\begin{array}{l}\text { Hipotesis Kelompok Kontrol terhadap Kelompok Eksperimen } \\
\text { SMP IT Nurul Yaqin Sorong }\end{array}$ & $\begin{array}{l}\mathrm{t} \quad \text { two sampel } \\
\text { independent }\end{array}$ & $\begin{array}{l}\text { thitung } \\
0.761\end{array}$ & $<$ ttabel $=2.06$ & H0 diterima \\
\hline $\begin{array}{l}\text { Hipotesis antar Kelompok Eksperimen SMP Negeri } 4 \text { Sorong dan } \\
\text { SMP IT Nurul Yaqin Sorong }\end{array}$ & $\begin{array}{l}\mathrm{t} \quad \text { two sampel } \\
\text { independent }\end{array}$ & $\begin{array}{l}\text { thitung } \\
1.263\end{array}$ & $<$ ttabel $=2.09$ & H0 diterima \\
\hline
\end{tabular}

Hasil analisis dari instrumen angket awal menunjukkan bahwa uji reabilitas diperoleh hasil reabel, karena dari pernyataan angket diperoleh nilai lebih besar dari pada Rtabel dan pernyataan dapat diukur secara konsisten atau tetap, sehingga dapat digunakan sebagai instrument penelitian. Selain itu, uji validitas dari 15 pernyataan menunjukan bahwa hanya ada 5 pernyataan yang menunjukan bahwa pernyataan angket valid, sedangkan 10 dari 15 pernyataan lainya menunjukan bahwa ngket tidak valid maka harus diperbaiki, karena pernyataan angket kurang tepat. Namun, dalam perbaikan tidak dihitung secara statistic melainkan mengunakan uji pakar. Berdasarkan hasil uji pakar maka instrumen dapat digunakan untuk instrumen suatu penelitian.

Hasil analisis dari instrumen angket akhir menunjukkan bahwa uji reabilitas memperoleh hasil reabel, sebab dari pernyataan angket diperoleh nilai lebih besar dari pada Rtabel dan pernyataan dapat diukur secara konsisten atau tetap, sehingga dapat digunakan sebagai instrument penelitian. Selain itu, uji validitas dari 15 pernyataan menunjukan bahwa hanya ada 9 pernyataan yang menunjukan pernyataan angket valid, sedangkan 4 dari 15 pernyataan lainya menunjukan bahwa angket tidak valid maka harus diperbaiki, karena pernyataan angket kurang tepat. Namun, dalam perbaikan tidak dihitung secara statistic melainkan mengunakan uji pakar. Berdasarkan hasil uji pakar maka instrumen dapat digunakan untuk instrumen suatu penelitian.

Hasil uji sampel P.4 diperoleh bahwa sampel antar kelompok kontrol dan kelompok eksperimen adalah homogen, maka dapat digunakan sebagai sampel penelitian. Selain itu, hasil uji sampel P.IT diperoleh bahwa sampel antar kelompok kontrol dan kelompok eksperimen adalah homogen, maka dapat digunakan sebagai sampel penelitian. Demikian pula hasil uji sampel P.4 dan P.IT diperoleh bahwa sampel antar kelompok eksperimen adalah homogen, maka dapat digunakan sebagai sampel penelitian.

Uji data hasil penelitian dengan menggunakan uji normalitas data dengan hasil uji normalitas tersebut dapat dijadikan patokan untuk mengambil keputusan tentang uji selanjutnya yakni uji hipotesis. Uji normalitas menyatakan bahwa tidak semua data berdistribusi normal maka uji hipotesis yang digunakan pada data yang berdistribusi normal adalah uji parametrik yakni menggunakan uji $\mathrm{t}$ two sampel dependent (sampel yang berhubungan) dan uji t two sampel independent (sampel bebas) sedangkan data yang tidak berdistribusi normal maka uji hipotesis yang digunakan adalah uji non parametrik yakni uji Wilcoxon Sing Rank (sampel yang berhubungan) dan Mann Whitney (sampel bebas).

Hasil penelitian kelompok kontrol P.4 diperoleh fakta berdasarkan uji hipotesis yakni hipotesis yang diterima adalah tidak ada perbedaan respon siswa di kelompok kontrol P.4 sebelum dan sesudah dilakukan pembentukan komunitas belajar mandiri. Demikian pula, dengan bukti dari perbandingan skor masing-masing item untuk angket awal dan akhir yang ditampilkan pada Gambar 3.1 yang dapat dikatakan 
setiap item tidak mengalami perubahan yang signifikan. Adapun yang terjadi perubahan yakni pada item nomor 6 yang menyatakan tentang untuk motivasi siswa belajar biologi, perlu dibentuknya komunitas belajar

mandiri mendapatkan skor yang semakin menurun sedangkan sebaliknya, item nomor 7 yang menyatakan tentang anda sering mengikuti bimbingan belajar atau les biologi di sekolah jika ada anjuran dari guru atau teman-teman saja mendapatkan skor yang semakin meningkat. Hal ini, membuktikan bahwa siswa di dikelompok kontrol P.4 tidak ada kesadaran untuk belajar sendiri jika tidak disuruh oleh guru. Hasil hipotesis kelompok kontrol awal dan akhir di P.4 diperoleh data seperti ditampilkan pada Tabel 3.2.

Hasil penelitian kelompok eksperimen P.4 diperoleh fakta berdasarkan uji hipotesis yakni hipotesis yang diterima adalah tidak ada perbedaan respon siswa di kelompok eksperimen P.4 sebelum dan sesudah dilakukan pembentukan komunitas belajar mandiri. Demikian pula dengan bukti dari perbandingan skor masing-masing item untuk angket awal dan akhir yang ditampilkan pada Gambar 3.1 yang dapat dikatakan setiap item tidak mengalami perubahan yang signifikan. Adapun yang terjadi perubahan yakni pada item nomor 4 yang menyatakan tentang untuk melatih siswa dalam berfikir krisis dan kreatif perlu dibentuk komunitas belajar mandiri mendapatkan skor yang semakin menurun sedangkan sebaliknya, item nomor 7 yang menyatakan tentang anda sering mengikuti bimbingan belajar atau les biologi di sekolah jika ada anjuran dari guru atau teman-teman saja mendapatkan skor yang semakin meningkat. Hal ini, membuktikan bahwa siswa dikelompok eksperimen P.4 tidak mengalami perubahan motivasi, karena perbandingan dengan sesama siswa yang mengikuti komunitas belajar mandiri, namun siswa yang mengikuti komunitas belajar mandiri ada perubahan ketika didalam kelas, karena siswa yang mengikuti komunitas belajar mandiri lebih percaya diri dan tingkat keingin tahuan semakin tinggi dibandingkan dengan siswa yang tidak mengikuti komunitas belajar mandiri. Selain itu, dibuktikan dari hasil wawancara siswa yang menyatakan bahwa dengan adanya komunitas belajar mandiri ini memberikan motivasi untuk belajar biologi dan cara belajarnya sangat mengasyikkan sehingga materi pelajaran mudah dipahami. Selain dari itu, guru memantau didalam kelas bahwa terjadi peningkatan motivasi siswa tang mengikuti komunitas belajar mandiri seperti pada Table 3.1 adapun peningkatan motivasi siswa dibuktikan pula dengan pernyataan item nomor 8 yang menyatakan bahwa siswa yang mengikuti komunitas belajar mandiri lebih fokus menyimak materi pembelajaran mendapatkan skor rata-rata tertinggi yakni 4.3. Selain itu, dibuktikan pula pada pernyataan item nomor 10 yang menyatakan bahwa belajar mandiri meningkatkan rasa keingin tahuan siswa dalam setiap materi pembelajaran mendapatkan skor tertinggi yakni 4.3. Hasil hipotesis kelompok eksperimen awal dan akhir di
P.4 diperoleh data seperti ditampilkan pada Gambar 3.1 dan hasil angket guru diperoleh data seperti ditampilkan pada Table 3.1

Hasil penelitian kelompok kontrol terhadap kelompok eksperimen P.4 diperoleh fakta berdasarkan uji hipotesis yakni hipotesis yang diterima adalah tidak ada perbedaan respon siswa antara kelompok kontrol terhadap kelompok eksperimen P.4 sesudah diberlakukan komunitas belajar mandiri. Demikian pula dengan bukti dari perbandingan skor masing-masing item untuk angket akhir pada kelompok kontrol terhadap kelompok eksperimen yang ditampilkan pada Gambar 3.1 yang dapat dikatakan setiap item tidak mengalami perubahan yang signifikan. Adapun yang terjadi perbedaan yakni pada kelompok kontrol item nomor 8 yang menyatakan tentang pembelajaran mengunakan komunitas belajar mandiri membuat anda jenuh mendapatkan rata-rata 4.4, sedangkan dikelas eksperimen terjadi perbedaan menunjukkan bahwa pernyataan item nomor 6 yang menyatakan bahwa komunitas belajar mandiri sangat bermanfaat untuk pembelajaran biologi mendapatkan skor rata-rata 4.8. Selain itu, dibuktikan dari hasil wawancara siswa yang menyatakan bahwa dengan adanya komunitas belajar mandiri ini memberikan motivasi untuk belajar biologi dan cara belajarnya sangat mengasyikkan sehingga materi pelajaran mudah dipahami. Selain dari itu, guru memantau didalam kelas bahwa terjadi peningkatan motivasi siswa tang mengikuti komunitas belajar mandiri seperti pada Tabel 3.1 adapun peningkatan motivasi siswa dibuktikan pula dengan pernyataan item nomor 8 yang menyatakan bahwa siswa yang mengikuti komunitas belajar mandiri lebih fokus menyimak materi pembelajaran mendapatkan skor rata-rata tertinggi yakni 4.3 selain itu, dibuktikan pula pada pernyataan item nomor 10 yang menyatakan bahwa belajar mandiri meningkatkan rasa keingintahuan siswa dalam setiap materi pembelajaran mendapatkan skor tertinggi yakni 4.3. Hal ini, membuktikan bahwa siswa dikelompok eksperimen P.4 mengalami perubahan motivasi dibandingan dengan siswa yang tidak mengikuti komunitas belajar mandiri. Namun, sesama siswa yang mengikuti komunitas belajar mandiri, tidak ada perubahan ketika didalam komunitas belajar mandiri, karena siswa yang mengikuti komunitas belajar mandiri sama dalam tingkat keingin tahuan materi pembelajaran yang ada dikomunitas belajar mandiri. Hasil hipotesis kelompok eksperimen awal dan akhir di P.4 diperoleh data seperti ditampilkan pada Gambar 3.1 dan hasil angket guru diperoleh data seperti ditampilkan pada Tabel 3.1.

Hasil penelitian kelompok kontrol P.IT diperoleh fakta berdasarkan uji hipotesis yakni hipotesis yang diterima adalah tidak ada perbedaan respon siswa di kelompok kontrol P.IT sebelum dan sesudah dilakukan pembentukan komunitas belajar mandiri. Demikian pula dengan bukti dari perbandingan 11 skor masing-masing item untuk angket awal dan akhir yang ditampilkan pada Gambar 3.1 yang dapat dikatakan 
setiap item tidak mengalami perubahan yang signifikan. Adapun yang terjadi perubahan yakni pada item nomor 7 yang menyatakan tentang anda sering mengikuti bimbingan belajar atau les biologi di sekolah jika ada anjuran dari guru atau teman-teman saja mendapatkan skor yang semakin meningkat. sedangkan persamaannya, item nomor 11 menyatakan tentang komunitas belajar mandiri membuat anda jenuh mendapatkan skor semakin meningkat. Hal ini, membuktikan bahwa siswa di dikelompok kontrol P.IT tidak ada keinginan untuk meluangkan waktu untuk belajar bersama teman-teman, karena mereka merasa bahwa komunitas belajar mandiri membuang-buang waktu. Hasil hipotesis kelompok kontrol awal dan akhir di P.4 diperoleh data seperti ditampilkan pada Gambar 3.1

Hasil penelitian kelompok eksprimen P.IT diperoleh fakta berdasarkan uji hipotesis yakni hipotesis yang diterima adalah tidak ada perbedaan respon siswa di kelompok eksperimen P.IT sebelum dan sesudah dilakukan pembentukan komunitas belajar mandiri. Demikian pula, dengan bukti dari perbandingan skor masing-masing item untuk angket awal dan akhir yang ditampilkan pada Gambar 3.1 yang dapat dikatakan setiap item tidak mengalami perubahan yang signifikan. Adapun yang terjadi perubahan yakni pada item nomor 5 yang menyatakan tentang komunitas belajar mandiri, membuat anda mengemukan pendapat saat belajar biologi. Selain itu, dibuktikan dari hasil wawancara siswa yang menyatakan bahwa dengan adanya komunitas belajar mandiri ini memberikan motivasi untuk belajar biologi dan cara belajarnya sangat mengasyikkan sehingga materi pelajaran mudah dipahami. Selain dari itu, guru memantau didalam kelas bahwa terjadi peningkatan motivasi siswa yang mengikuti komunitas belajar mandiri seperti pada Tabel 3.1 adapun peningkatan motivasi siswa dibuktikan pula dengan pernyataan item nomor 7 yang menyatakan tentang belajar mandiri dapat mengeplorasikan diri siswa mendapatkan skor tertinggi yakni 4.3, selain itu dibuktikan pula pada item nomor 9 yang menyatakan tentang belajar mandiri dapat meningkakan prestasi siswa mendapatkan skor tertinggi yakni 4.3 selain itu, dibuktikan pula pada pernyataan item nomor 10 yang menyatakan bahwa belajar mandiri meningkatkan rasa keingin tahuan siswa dalam setiap materi pembelajaran mendapatkan skor tertinggi yakni 4.3. Hal ini, membuktikan bahwa siswa di dikelompok eksperimen P.IT termotivasi minat belajar dengan adanya komunitas belajar mandiri. Hasil hipotesis kelompok eksperimen awal dan akhir di P.IT diperoleh data seperti ditampilkan pada Tabel 3.2.dan hasil angket guru diperoleh data seperti ditampilkan pada Tabel 3.1.

Hasil penelitian kelompok kontrol terhadap kelompok eksperimen P.IT diperoleh fakta berdasarkan uji hipotesis yakni hipotesis yang diterima adalah tidak ada perbedaan respon siswa antara kelompok kontrol terhadap kelompok eksperimen P.IT sesudah diberlakukan komunitas belajar mandiri. Demikian pula dengan bukti dari perbandingan skor masing-masing item untuk angket akhir pada kelompok kontrol terhadap kelompok eksperimen yang ditampilkan pada Gambar 3.1 yang dapat dikatakan setiap item tidak mengalami perubahan yang signifikan. Adapun yang terjadi perubahan yakni pada item nomor 1 yang menyatakan tentang pembentukan komunitas belajar mandiri menarik dalam pembelajaran biologi, kelompok eksperimen mendapatkan skor yang semakin meningkat dibandingkan kelompok kontrol. selain itu, diperoleh perubahan pada item nomor 5 yang menyatakan tentang komunitas belajar mandiri membuat anda dapat mengemukan pendapat saat belajar biologi, kelompok eksperimen mendapatkan skor yang semakin meningkta dibandingkan kelompok kontrol. Selain itu dibuktikan dari hasil wawancara siswa yang menyatakan bahwa dengan adanya komunitas belajar mandiri ini memberikan motivasi untuk belajar biologi dan cara belajarnya sangat mengasyikkan sehingga materi pelajaran mudah dipahami. Selain dari itu, guru memantau didalam kelas bahwa terjadi peningkatan motivasi siswa yang mengikuti komunitas belajar mandiri seperti pada Tabel 3.1 adapun peningkatan motivasi siswa dibuktikan pula dengan pernyataan item nomor 7 yang menyatakan tentang belajar mandiri dapat mengeplorasikan diri siswa mendapatkan skor tertinggi yakni 4.3 selain itu, dibuktikan pula pada item nomor 9 yang menyatakan tentang belajar mandiri dapat meningkakan prestasi siswa mendapatkan skor tertinggi yakni 4.3. Selain itu, dibuktikan pula pada pernyataan item nomor 10 yang menyatakan bahwa belajar mandiri meningkatkan rasa keingintahuan siswa dalam setiap materi pembelajaran mendapatkan skor tertinggi yakni 4.3. Hal ini, membuktikan bahwa siswa kelompok eksperimen P.IT mengalami perubahan motivasi dibandingan dengan kelompok kontrol tidak mengikuti komunitas belajar mandiri. Namun, sesama siswa yang mengikuti komunitas belajar mandiri, tidak ada perubahan ketika didalam komunitas belajar mandiri, karena siswa yang mengikuti komunitas belajar mandiri sama dalam tingkat keingin tahuan materi pembelajaran yang ada dikomunitas belajar mandiri. Hasil hipotesis kelompok eksperimen awal dan akhir di SMP Negeri 4 Sorong diperoleh data seperti ditampilkan pada Gambar 3.1 dan hasil angket guru diperoleh data seperti ditampilkan pada Table 3.1.

Hasil penelitian kelompok eksperimen P.4 terhadap kelompok eksperimen P.IT diperoleh fakta berdasarkan uji hipotesis yakni hipotesis yang diterima adalah tidak ada perbedaan respon siswa antara kelompok eksperimen P.4 terhadap kelompok eksperimen P.IT sesudah diberlakukan komunitas belajar mandiri. Demikian pula dengan bukti dari perbandingan skor masing-masing item untuk angket akhir pada kelompok eksperimen P.4 terhadap kelompok eksperimen P.IT yang ditampilkan pada Gambar 3.1 yang dapat dikatakan setiap item tidak mengalami perubahan yang signifikan. Selain itu dibuktikan dari hasil wawancara siswa yang menyatakan bahwa dengan adanya komunitas belajar 
mandiri ini memberikan motivasi untuk belajar biologi dan cara belajarnya sangat mengasyikkan sehingga materi pelajaran mudah dipahami. Selain dari itu, guru memantau didalam kelas bahwa terjadi peningkatan motivasi siswa yang mengikuti komunitas belajar mandiri seperti pada Tabel 3.1 adapun peningkatan motivasi siswa dibuktikan pula dengan pernyataan item nomor 7 yang menyatakan tentang belajar mandiri dapat mengeplorasikan diri siswa mendapatkan skor tertinggi yakni 4.3 selain itu, dibuktikan pula pada item nomor 9 yang menyatakan tentang belajar mandiri dapat meningkakan prestasi siswa mendapatkan skor tertinggi yakni 4.3 selain itu, dibuktikan pula pada pernyataan item nomor 10 yang menyatakan bahwa belajar mandiri meningkatkan rasa keingin tahuan siswa dalam setiap materi pembelajaran mendapatkan skor tertinggi yakni 4.3. Hal ini, membuktikan bahwa perbandingan antara kelompok eksperimen P.4 dan kelompok eksperimen P.IT tidak mengalami perbedaan motivasi siswa sesudah diberlakukan komunitas belajar mandiri. Hasil hipotesis antara kelompok eksperimen P.4 terhadap P.IT diperoleh data seperti ditampilkan pada Gambar 3.1 dan hasil angket guru P.4 dan P.IT diperoleh data seperti ditampilkan pada Tabel 3.1.

Hal ini seirama dengan penelitian yang dilaksanakan oleh Nurdin Ibrahim yang menyatakan bahwa 1) terdapat hubungan positif antara belajar mandiri (X1) dengan hasil belajar pendidikan agama Islam (X1 dan $\mathrm{Y}=0.685)$. 2) Terdapat hubungan positif antara motivasi berprestasi (X2) dengan hasil belajar pendidikan agama Islam (X2 dan $\mathrm{Y}=0,631)$, dan 3) Terdapat hubungan positif antara belajar mandiri (X1) dan motivasi berprestasi (X2) secara bersama-sama dengan hasil belajar pendidikan agama Islam (X1 danX2 dengan $\mathrm{Y}=0,734)$. Mengapa demikian?. Karena Kemandirian dalam belajar perlu diberikan kepada siswa supaya mereka mempunyai tanggung jawab dalam mengatur dan mendisiplinkan dirinya dan dapat mengembangkan kemampuan belajar atas kemauan sendiri dan secara harfiah, motivasi (Motivation) berasal dari bahasa latin "movere" yang berarti to move atau menggerakkan.

\section{KESIMPULAN}

Hasil hipotesis penelitian ini dapat disimpulkan bahwa : 1. Berdasarkan hasil uji hipotesis respon siswa di P.4 kelompok kontrol antara sebelum dan sesudah dibentuk komunitas belajar mandiri. Hasil yang diperoleh yakni $0.624>0.05$ yang menunjukan bahwa respon siswa di P.4 kelompok kontrol antara sebelum dan sesudah dibentuk komunitas belajar mandiri tidak ada perbedaan. 2. Berdasarkan hasil uji hipotesis respon siswa di P.4 kelompok eksperimen antara sebelum dan sesudah dibentuk komunitas belajar mandiri. Hasil yang diperoleh yakni thitung $=0.048<$ tabel $=2.31$ yang menunjukan bahwa respon siswa di P.4 kelompok eksperimen antara sebelum dan sesudah dibentuk komunitas belajar mandiri.tidak ada perbedaan. 3 . Berdasarkan hasil uji hipotesis respon siswa antara kelompok kontrol terhadap kelompok eksperimen di P.4 sesudah dilakukan pembentukan komunitas belajar mandiri. Hasil yang diperoleh yakni $0.869>0.05$ yang menunjukan bahwa respon siswa antara kelompok kontrol terhadap kelompok eksperimen di P.4 sesudah dilakukan pembentukan komunitas belajar mandiri tidak ada perbedaan. 4. Berdasarkan hasil uji hipotesis respon siswa kelompok kontrol di P.IT antara sebelum dan sesudah dilakukan pembentukan komunitas belajar mandiri. Hasil yang diperoleh yakni thitung $=0.000<$ ttabel $=2.18$ yang menunjukan bahwa respon siswa kelompok kontrol di P.IT antara sebelum dan sesudah dilakukan pembentukan komunitas belajar mandiri tidak ada perbedaan. 5. Berdasarkan hasil uji hipotesis respon siswa kelompok eksperimen di P.IT antara sebelum dan sesudah dilakukan pembentukan komunitas belajar mandiri. Hasil yang diperoleh yakni thitung $=-1.167<$ ttabel $=2.18$ yang menunjukan bahwa respon siswa kelompok eksperimen di P.IT antara sebelum dan sesudah dilakukan pembentukan komunitas belajar mandiri tidak ada perbedaan. 6 . Berdasarkan hasil uji hipotesis respon siswa antara kelompok kontrol terhadap kelompok eksperimen di P.IT sesudah dilakukan pembentukan komunitas belajar mandiri. Hasil yang diperoleh yakni thitung = $0.610<$ ttabel $=2.06$ yang menunjukan bahwa respon siswa antara kelompok kontrol terhadap kelompok eksperimen di P.IT sesudah dilakukan pembentukan komunitas belajar mandiri tidak ada perbedaan. 7 . Berdasarkan hasil uji hipotesis respon siswa antara kelompok eksperimen di P.4 terhadap kelompok eksperimen P.IT sesudah dilakukan pembentukan komunitas belajar mandiri. Hasil yang diperoleh yakni thitung $=1.128<$ ttabel $=2.09$ yang menunjukan bahwa hipotesis respon siswa antara kelompok eksperimen di P.4 terhadap kelompok eksperimen P.IT sesudah dilakukan pembentukan komunitas belajar mandiri tidak ada perbedaan. Berdasarkan hasil penelitian ini memperoleh fakta bahwa respon siswa yang mengikuti komunitas belajar mandiri lebih baik dibanding dengan siswa yang tidak mengikuti komunitas belajar mandiri.

\section{DAFTAR PUSTAKA}

[i] Badan Standar Nasional Pendidikan. Undang Undang SISDIKNAS No. 20 Tahun 2003.

[ii] Gary Dworkin, J. Saha, Teacher Burnout And Perceptions Of A Democratic School Environment. International Education Journal Vol 4, No 2, 2003

[iii] Mustafa Yunus Eryaman. Progressive Education: Antecedents Of Educating For Democracy. International Journal Of Progressive Education, Volume 9 Number 1, 2013.

[iv] Michael Prince J. Does Active Learning Work? A Revie Of The Research Study. Engr Education , 23 (3) 223-231, 2004.

[v] Alan Chapman. Free Resources @ Www.Businessballs.Com . 2006.

[vi] W. Cooper, A Tool To Promote Critical Thinking Skills: Journal Writing In Career And Technical Education,

[vii] Brand, B. Rigor And Relevance, A New Vision For Career And Technical Education. 
Paper Presented At The National Centers For Career And Technical Education Webcast. Retrieved February 10, 2006, From Http://Www.Nccte.Org/Webcasts/Description.As px? Wc=134 , 2004.

[viii] David W. McMillan and David M. Chavis George. Peabody College of Vanderbilt University, Journal of Community Psychology. Volume 14, January 1986. Sense of Community: A Definition and Theory, 1986.

[ix] Salamuddin, Harun And Abdullah,

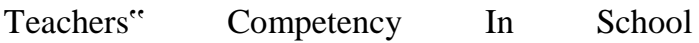
Extra-Curricular Management. (Innovation And Pedagogy For Lifelong Learning): 49-55, 2011

[x] Supriatna Mamat. Pendidikan Karakter Melalui Ekstrakurikuler, 2010.

[xi] Heyneman, S. P. Private Tutoring And Social Cohesion. Peabody Journal of Education,
86:2, $183-188,2011$

[xii] Ryan, M, Delany, $L$ dan Harmon, $C$, Micro-Level Determinants Of Lecture Attendance And Additional Study-Hours, 2010.

[xiii] Emst, J. V. A Comparison Of Traditional And Hybrid Online Instructional Presentation In Communication Technology. Journal of Technology Education. Vol. 19 No. 2, 2008.

[xiv] Rennie, L.J., E. Feher, L.D. Dierking, dan J.H.Falk. "Toward An Agenda For Advancing Research On Science Learning In Outof-School Settings." Journal of Research In Science Teachinplloki., $\quad$ Jag 40: 112-120 (2003)

[xv] Sugiyono. Metode Penelitian Kuantitatif, Kualitatif Dan $R$ Dan B. Bandung: Alfabeta, 2009. 